\title{
BILTENU NA POT
}

\section{THE BULLETIN SETS OUT ON ITS WAY}

Pred vami je prva številka biltena. Pripravili smo ga za uresničevanje zlasti treh ciljev:

1. Celoten koncept sodobnega vojaškega managementa sloni na visoko usposobljenih, motiviranih kadrih. Ugotavljamo, da obstoječih prednosti, ki jih nudi velika koncentracija izkušenj in znanja zaposlenih v Slovenski vojski, ne izkoriščamo dovolj. Glasilo nam daje priložnost, da bomo znanja, spoznanja in izkušnje posredovali zaposlenim v Slovenski vojski in tudi širšemu okolju.

2. Posledica globalizacije in liberalizacije tržišč je, in tudi vedno bo, odhajanje najboljših kadrov iz organizacijskih enot. $Z$ vzpostavitvijo pogojev za razvoj kadrov, katerega del je možnost kreativnega delovanja v obliki objavljanja strokovnih člankov, bomo na nek način vplivali na urejeno prehajanje med organizacijskimi enotami in zaustavljali nekontrolirane odhode iz sistema ter strokovne članke tudi upoštevali pri opredeljevanju predlogov za napredovanje.

3. Z razporeditvijo na določeno dolžnost pridobi posameznik položajno avtoriteto. Da je bil izbran, je moral izpolnjevati predpisane pogoje, torej imeti formalno izobrazbo, ustrezne delovne izkušnje in zlasti mora biti vojaškostrokovno usposobljen. Navedene pogoje lahko strnemo v strokovno avtoriteto častnika, ki je enakega pomena kot položajna avtoriteta, vendar marsikdaj težje dosegljiva. Prav možnost objavljanja strokovnih člankov v našem glasilu lahko bistveno vpliva na upoštevanje strokovne avtoritete zaposlenih v Slovenski vojski. Vsi bomo imeli možnost strokovnega dokazovanja in s tem nas bodo sodelavci upoštevali kot strokovnjake, hkrati pa bomo tudi strokovno rasli, saj ne bomo objavljali znanih vsebin, pač pa novosti in znanja, spoznanja ter izkušnje iz drugih okolij.

Pričakujem, da bomo izkoristili dano priložnost in želim, da postane glasilo informator vseh zaposlenih, ena pomembnih literatur za izpopolnjevanje zaposlenih v Slovenski vojski, vzpostavljanje organizacijske kulture in tudi razvoj Slovenske vojske. 